\title{
Meta-Disciplinarity as a Factor of Success of a Modern Person: A Productive Approach
}

\author{
Karine R. Khachaturova ${ }^{1 *[O R C I D ~ 0000-0001-9537-7086], ~}$ \\ Roza M. Sherayzina 2[ORCID 0000-0002-7358-0689], \\ Marina V. Alexandrova 2[ORCID 0000-0003-1745-4730], \\ Irina A. Donina 2[ORCID 0000-0002-8191-196X]
}

\author{
${ }^{1}$ General Education Secondary (High) School No. 129, Saint Petersburg, Russia \\ ${ }^{2}$ Yaroslav-the-Wise Novgorod State University, Veliky Novgorod, Russia \\ karinah@inbox.ru
}

\begin{abstract}
In modern conditions of transformation of socioeconomic system, the task to improve the efficiency of activities and develop the professionalism of workers in all areas is becoming increasingly relevant. In this regard, the acute issue of modernizing higher and general secondary (high) education arises, in order to prepare a competent and successful personality. At the same time, traditional forms of educational activities are not justified as they are mainly aimed at forming the definite system of knowledge, abilities and skills restricted by the frames of program material. The development of personality is only an accompanying effect of such a training system. Meanwhile, currently, more and more attention is paid to the formation of meta-competencies or overdisciplinary, over-professional abilities and traits which allow the personality to become successful and effective in all living spheres, including professional one. The article presents the results of a theoretical analysis of the problem of developing meta-competences by means of productive education, as well as data from an experimental study of the effectiveness of productive education in the process of developing meta-competences of university students. The purpose of the study was to highlight main criteria, as well as methods and means of forming meta-competences, and to determine the role of productive education in this process. The objectives of the study included a description and analysis of problems of vocational education in the conditions of development of an innovative digital economy. Among the criteria for the development of meta-competences of a professional the authors highlighted readiness for innovations, readiness for self-development, ability to critically think, creativity, digital and functional literacy, emotional intelligence. As research methods, the authors used both theoretical techniques of an analysis, synthesis and material systematization, and diagnostic techniques aimed at an empirical assessment of the level of formation of the main components of a metacompetence. According to the study results, modern education should be aimed not at knowledge but at a person capable of self-development on the basis of acquired knowledge, abilities and experience. A similar effect can be achieved through productive education implemented under the conditions closed to natural professional and everyday activities as much as possible. Forming the conditions stimulating a person to creatively search, make non-standard and effective decisions, critically think is the essence of modern education.
\end{abstract}

Keywords: development of personality, innovative development, meta-competences, productive education, professional growth, transformation of education

\section{INTRODUCTION}

Currently, the need to use innovative directions and forms of work, in order to develop the personality of a student, is becoming increasingly clear.
As the practice and data from a number of studies [1-4] have shown, the personal effectiveness largely depends on the ability to rapidly and impartially assess the situation, figure out the problem and make the correct decision, as well as 
the ability to adapt to various, sometimes unforeseen, non-standard and complicated situations. Hence, we can conclude that the most effective means of developing these abilities is education and training based on real living situations. In addition, a person should be placed in such conditions, in which they will inevitably look for a practical way out and take certain steps to overcome difficulties. Such an opportunity is provided by methods of productive education, or education on the basis of productive activities in real social situations. In education, such a method involves joint practical fruitful activities of the teacher and the student, while they realize relations of cooperation and co-creation [5].

At the same time, the analysis of literary sources allowed us to reveal a contradiction between the need to form a personality of a new type and the lack of pedagogical technologies, methodical support, teaching staff capable to realize such an innovative process of education and upbringing. This contradiction, in turn, creates a precondition for a radical reconstruction of the entire educational system, including higher pedagogical one aimed at training specialists in the field of innovative pedagogy.

To correct the situation is possible by integrating two leading areas: conceptual approaches to lifelong education and productive learning.

\section{MATERIALS AND METHODS}

The purpose of this study is to reveal opportunities and assess the effectiveness of methods of productive learning in the process of development of meta-competences of students.

To achieve the goal, the following tasks were set:

- to characterize productive learning as an innovative form of vocational education;

- to highlight the essence of meta-competences and determine their significance in the modern world;

- to assess the effectiveness of methods of productive learning in the development of meta-competences of future specialists.

The methodological basis of the study was formed by the provisions of domestic and foreign scientists regarding the essence and role of productive education [2, 5-7], the concept and criteria for the formation of meta-competences of a professional [4, 8-10], the methods of studying the effectiveness and success of the modernization of educational systems [11-14].

The research methods are theoretical analysis, synthesis, deduction, generalization; empiric study of the development level of students' metacompetences; practical realization of a system of productive student learning.

The main criteria for the development of students' meta-competences were identified as [2]:

- ability and readiness for lifelong education;

- readiness for constant improvement, relearning and self-learning, professional mobility, striving for new things;

- ability to critically think;

- ability and readiness for reasonable risk, creativity and entrepreneurship;

- ability to independently work and readiness for a team work, readiness to work in highly competitive environment, in a mode of high uncertainty and rapid change in task conditions;

- digital and functional literacy;

- emotional intelligence.

Development and standardization of the assessment were based on the recommendations on diagnostics for meta-competences by M.V. Osipov [9]. The following research techniques were used: questioning; creativity questionnaire by D. Johnson; technique for determining critical thinking level (Yu.F. Gushchin, N.V. Smirnova); surveillance; DIGLIT technique of Digital Literacy measurement; diagnostics for Emotional Intelligence (N. Hall).

\section{RESULTS}

Modern educational standards and programs for all educational levels are based on the following main principles and approaches: system-activity, personal, environmental, situational approaches. Summarizing the priority concepts of education modernization, we can conclude that the main target in all of these approaches is the formation of a successful, comprehensively developed, labile personality able to effectively exist and realize themselves in a dynamically changing society.

Currently, traditional forms and methods of classical pedagogy do not justify themselves, since they form a rather narrow range of skills, abilities and ideas of students. Today, modern society needs 
specialists possessing a wide range of competences (both personal and professional) which allow them to present themselves in the best light and effectively fulfill the assigned tasks, as well as successfully adapt to changing conditions of life and activities; perform self-regulation, self-control and self-correction; constantly grow above themselves. In this regard, the benchmark for education and upbringing is not a definite system of knowledge, skills and abilities, but an individual competent in various areas. In other words, we are not talking about a discipline-oriented or professional competence, but about a meta-competence which allows an individual to become successful, demanded and realized in all living areas [3].

In this regard, the main problem is to identify opportunities and types of teaching activities, innovative technologies and forms of work that contribute to the formation of such a competence of a personality.

In the modern socio-cultural situation, characterized by the dynamism of changes in the economic, cultural, industrial, political, social spheres, increased competition and increased requirements for the personality of a professional, the main task of education is to train qualified personnel who have not only a high level of professional competences, but also developed personal qualities, over-discipline (meta-discipline) competences, social activity, creativity and nonstandard thinking.

Similar guidelines are outlined in the "Strategy for Development of Education in the Russian Federation for Period up to 2025", which directs teachers to ensure the social and civic development of young people; the formation of spiritual and moral, value-meaning orientation, internal positive motivation for self-determination and selfdevelopment, continuous personal and professional growth, self-actualization and self-realization in life, society and profession [4].

Today, an effective and demanded metadisciplinary approach makes it possible to take into account rapidly changing conditions of modern life, economic, socio-political and cultural development, as well as peculiarities of their influence on the formation and socialization of the individual, the nature of their value orientations, worldview attitudes and life ideals [7].

The idea of productive learning originated in the works of P.P. Blonsky, A.S. Makarenko, K.D. Ushinsky and other scientists who identified creativity and personal growth as the leading guidelines for the development of educational practice. According to these authors, mental and physical labor should become the main source of personality development.

Modern researchers, employees of the Institute for Productive Learning in Europe, consider productive learning as a type of educational activity, the purpose of which is the development and socialization of the individual in parallel with the development and improvement of society itself [12].

Such an approach determines an orientation towards a person's success in all types of personally and socially significant activities, towards a product and understanding of activity in a group of students with the direct participation and support of teachers.

Thus, the concept of productive learning, which is based on a principle of activities, shifts priorities from the formation of knowledge, skills and abilities to the implementation of an individual educational program. Thus, the training and development of an individual becomes self-learning and selfdevelopment based on understanding their own experience and developing mechanisms for increasing their own efficiency, adaptability and competitiveness in society.

According to G.K. Parinova, S.Yu. Tsikunov, E.V. Shubina, the basis of productive learning is "a change in the social and living role of knowledge and cognitive creative abilities of a person" [10]. Thus, the unity of knowledge and experience, awareness of their role in the development of the creative potential of an individual comes to the fore.

Learning to act effectively in any life situations, a person involuntarily seeks to find ways and solutions, relying on their existing knowledge and experience. At the same time, failures are considered as an incentive to replenish missing knowledge and develop mechanisms for overcoming difficulties and contradictions. Productive learning in this sense becomes an analogue of personality selfdevelopment, the development of adaptive mechanisms based on a creative approach and creativity of thinking. At the same time, a person's motivation for cognition, self-development and understanding of themselves and their role in the changing world increases. In modern conditions of life, people are increasingly taking responsibility for a large number of social endeavors in order to find work, improve their social, intellectual, professional level, well-being, prestige, and become a soughtafter specialist. At the same time, they strive to 
realize their knowledge and experience in various fields of activity, professional, cultural and social life.

Today, productive learning is an established pedagogical system, the purpose of which is to help and support the individual in their personal and professional development, self-determination and socialization by creating and implementing their own individual educational route, based on the implementation of productive activities and ensuring the disclosure of creative potential.

At the same time, modern authors focus on the need to organize productive activities in the process of interpersonal interaction and cooperation [13].

Summarizing the approaches of different authors to the specifics of organizing productive learning, we can highlight the main conceptual features that underlie it:

- a high level of personal motivation to carry out socially significant activities;

- the problematic nature and reality of life situations, in the process of resolving which the individual gains valuable experience and knowledge, learning in an atmosphere of cooperation and co-creation;

- focus on social development and ensuring their own contribution to it;

- perception of one's own trajectory of development, inextricably linked with the development of society and culture;

- practical focus and product orientation of activities.

At the same time, "the educational paradigm of productive learning and productivity as a constant participation in the process of social development leads to a new organization of special knowledge, through which the learner uses knowledge as a model and tool of activity, which allows everyone to develop their own forms of practical and methodological activity" [11].

The modern interpretation of such special knowledge implies not only the presence of ideas about the world, its laws, processes and phenomena, but also about the ways of interaction with the world, i.e. the ways of self-realization, selfdevelopment, comprehension of the value and meaning of life, implementation of socially significant activities based on life and professional experience. This concept fully correlates with the concepts of meta-skills, meta-knowledge, metaabilities and meta-competences as the basis for ensuring the competitiveness of a specialist in the labor market.

The term meta-competence is considered by scientists from different positions. So, S.A. Mikhaylichenko considers this phenomenon as a set of competences and personal qualities that allow a person to successfully form new knowledge and competences [11]. M.O. Levadnyaya and A.Yu. Petrovchuk characterize meta-competence as a "superstructure", the highest degree of competence and professional development of a personality, contributing to an effective transition to a new level of cognition and personal growth [8]. Metacompetences are competences of the highest creative level, representing the result of meta-disciplinary learning and personality development [6]. At the same time, K. Aramyan and a number of other authors note that meta-competences are developed on the basis of the ability for effective interpersonal interaction, teamwork, and making non-standard decisions in a specific situation [14].

Thus, we can conclude that the development of meta-competences occurs in the process of creative cooperation, the interaction of a group of people in the course of solving life contradictions, collisions and professional challenges. In this sense, it becomes obvious that in order to develop this personality trait, it is important to use appropriate innovative methods of teaching and upbringing aimed at developing the personality in the course of productive activity.

In the course of our research, the task was set to assess the current state of the use of productive learning in modern educational institutions. The study was carried out on the basis of the Department of Pedagogy of the Raoul Wallenberg Institute of Special Pedagogy and Psychology in St. Petersburg (Russia). The study involved 25 teachers and 150 students of 4-5 years of training (75 students made up the experimental group of the study, 75 students made up the control group). The ascertaining stage of the experiment showed the results presented in Table 1 . Thus, the study showed that modern students had meta-competences mainly at the intermediate level (average score is 4.8 on a 10-point scale). At the same time, the most developed competences turned out to be in the field of digital and functional literacy, and the least developed competences are creativity of thinking and readiness to innovate.

Such results necessitated the development and implementation of a program for the development of students' meta-competences in the process of productive learning. 
Table 1. Indicators of development of components of meta-competences of students at ascertaining stage of experiment, \%

\begin{tabular}{|l|c|c|c|c|c|c|}
\hline \multicolumn{1}{|c|}{ Level } & $\begin{array}{c}\text { Readiness for } \\
\text { innovations }\end{array}$ & $\begin{array}{c}\text { Readiness for self- } \\
\text { improvement }\end{array}$ & $\begin{array}{c}\text { Ability for critical } \\
\text { thinking } \\
\text { Experimental group }\end{array}$ & Creativity & $\begin{array}{c}\text { Digital and } \\
\text { functional literacy }\end{array}$ & $\begin{array}{c}\text { Emotional } \\
\text { intelligence }\end{array}$ \\
\hline High & 12 & 25 & 32 & 17 & 55 & 35 \\
\hline Intermediate & 45 & 40 & 50 & 37 & 30 & 50 \\
\hline Low & 43 & 35 & 18 & 46 & 15 & 15 \\
\hline \multicolumn{7}{|c|}{ Control group } \\
\hline High & 15 & 20 & 33 & 15 & 52 & 33 \\
\hline Intermediate & 40 & 42 & 52 & 35 & 35 & 54 \\
\hline Low & 45 & 38 & 15 & 50 & 13 & 13 \\
\hline
\end{tabular}

Source: Compiled by the authors based on the study results

For three months, the students of the experimental group were involved in solving various kinds of professional and life situations in conditions as close as possible to real activities (at work, during an exam, in social and leisure activities).

At the same time, the formation of students' meta-competence was carried out through the passage of the main stages of professional and personal self-development:

- setting goals, showing initiative, putting forward ideas;

- involvement in the development and implementation of design and management solutions;

- $\quad$ ensuring the reflection of activities.
During the experiment, students implemented a number of social initiatives in the field of management, social assistance, public administration. Some of the projects were tested on the basis of various enterprises and government agencies. Thus, the situation of real professional activity was ensured, taking into account all the opportunities, prospects and risks.

After the implementation of the program, repeated diagnostics of the level of formation of meta-competences was carried out, which showed a significant increase in the development of all studied components in representatives of the experimental group. At the same time, the dynamics of the competences of students in the control group was not so significant (Figure 1).

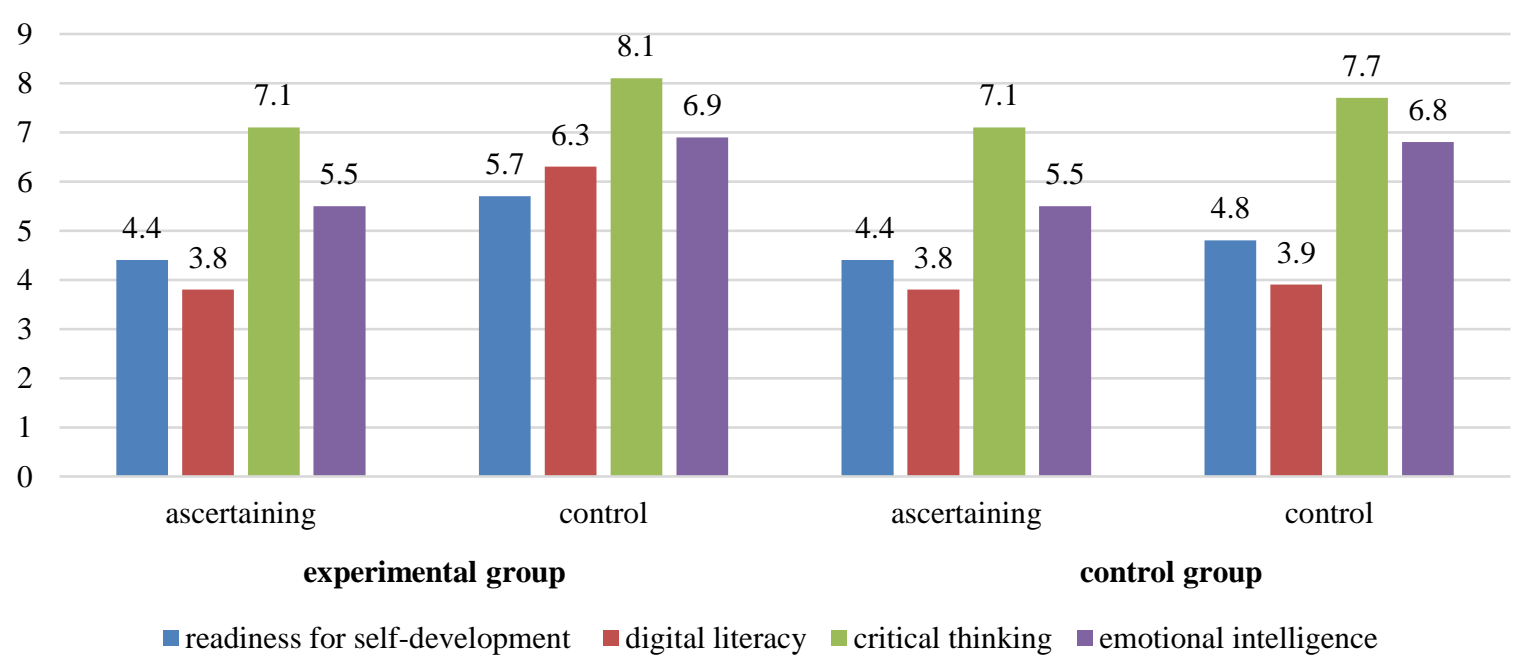

Figure 1. Dynamics of development of students' meta-competences during the experiment Source: Compiled by the authors based on the results of the survey

\section{DISCUSSION}

Thus, based on the analysis of the results of the study of the dynamics of the development of students' meta-competences, it was revealed that the methods of productive education were a promising way to increase the success and effectiveness of the individual. Productive education makes it possible for a person to feel themselves in a real professional situation, to see real problems, to realize that not 
only the result of work, but also career growth, material wealth, status in society, professional level and authority largely depend on their solution. Thus, productive education is associated with problem learning and case study methods, but it is carried out in conditions that are closer to life and practical professional activity. Such conditions form an effective environment for the development of creativity, critical thinking, readiness for innovations and self-development, emotional intelligence. These characteristics form the basis of the metacompetences of a modern specialist.

The results obtained confirm the assumptions and theoretical foundations presented in the works of M.V. Osipov [4, 9], M.O. Levadnyaya [8], G.K. Parinova [10] and other scientists.

\section{CONCLUSION}

Modern society requires competent, qualified personnel able to quickly and effectively solve emerging problems, thus contributing to the advancement of economy, cultural and spiritual growth, the social development of the state, the implementation of fruitful international cooperation. Such specialists can be formed in the conditions of innovative productive education, during which a student develops a complex of personal and professional knowledge, skills, abilities, and competences, united by the concept of metacompetence.

In the course of studying the literature on the development of meta-competences, we identified the main components and features of this phenomenon, indicated the conditions and approaches to their formation. The essence of productive education as an education based on actions in real life and professional situations was considered. In addition, an experimental study was carried out to create conditions for the development of students' metacompetences in the process of productive education. The effectiveness of this approach and the feasibility of using it in training qualified personnel for the Russian economy were proved.

So, the goal was achieved, the tasks were solved and the theoretical provisions set forth in the works of many scientists in the field of development and modernization of education were confirmed. The obtained results of the questionnaire survey and correlation of teachers and students of the Institute of Special Pedagogy and Psychology can be used in the design of the educational environment and educational technologies in institutions of general, secondary, and higher professional education.

\section{AUTHOR'S CONTRIBUTION}

The authors made an equal contribution to the study: collection and analysis of material; definition of goals and objectives, research methods; formulation and scientific substantiation of conclusions, registration of key research results in the form of an article.

\section{REFERENCES}

[1] T. Usheva, "Experience of Developing Reflexive Competence in a Future Teacher at a University" [Opyt razvitiya refleksivnoy kompetentnosti budushchego pedagoga $\mathrm{V}$ universitete], in Ed. by N.V. Martynova, "Theoretical and practical aspects of pedagogy" [Teoreticheskiye i prakticheskiye aspekty pedagogiki], pp. 61-68. Cheboksary: ID "Sreda", 2020. 114 p. DOI: 10.31483/r-86137

[2] A. Rubtsova, "Socio-linguistic innovations in education: Productive implementation of intercultural communication", in Proceedings of the IOP Conference Series: Materials Science and Engineering, Saint-Petersburg, November 21-22, Saint-Petersburg: Institute of Physics Publishing, 2019, vol. 497, p. 012059. DOI 10.1088/1757-899X/497/1/012059

[3] M. Temnikova, "Problem-Productive Strategies in Students' Education for Solving Mathematical Text Tasks in Primary School", Pedagogy, 2018, vol. 90(2), pp. 223-235. (In Russ.).

[4] M.V. Osipov, "Pedagogical conditions for the formation of metacompetence of students", Modern High Technologies, 2020, vol. 10. pp. 219-225. (In Russ.). DOI: $10.17513 /$ snt.38283

[5] B. Takvorian-Solakian, "The Concept of Productive Education”, Pedagogy, 2019, vol. 91(1), p. 33-46. (In Russ.).

[6] A. Rubtsova, N. Almazova, "Productive Model of Foreign Languages Learning, Realities and Prospects", in Proceedings of the International Conference Communicative Strategies of Information Society (CSIS 2018), 2019, pp. 319-324. DOI: $10.2991 /$ csis-18.2019.65

[7] E. Kolomiiets, "Productive learning technology as means of education quality provision", Continuing professional education: theory and practice, 2019, vol. 1(58), pp. 42-45. DOI: 10.28925/1609-8595.2019.1.4245 
[8] M.O. Levadnyaya, A.Yu. Petrovchuk, "Metacompetences and their importance in education" [Metakompetentsii i ikh znacheniye $\mathrm{v}$ obrazovanii], in Proceedings of the International Student Scientific Conference "Student Scientific Forum, 2019. (In Russ.). Retrieved from https://scienceforum.ru/2019/article/201801194 0

[9] M.V. Osipov, V.A. Shershneva, "Diagnostics of formation of metacompetence of the subject of education activity", Prospects of Science and Education, 2020, vol. 3(45), pp. 52-64. (In Russ.). DOI: $10.32744 /$ pse.2020.3.4

[10] G.K. Parinova, S.Yu. Tsikunov, E.V. Shubina, "Productive education in career guidance work" [Produktivnoye obrazovaniye v proforientatsionnoy rabote], Vocational guidance [Professional'naya orientatsiya], 2017, vol. 1, pp. 165-173. (In Russ.).

[11]S.A. Mikhaylichenko, Yu.Yu. Buryak, Yu.A. Afanaskova, "Meta-competences as the basis for successful self-realization of graduates in the labor market" [Metakompetentsii kak osnova uspeshnoy samorealizatsii vypusknikov na rynke truda], in Proceedings of the VIII ISPC dedicated to the 10th anniversary of the
Regional Scientific and Methodological Center for Professional Adaptation and Employment of Specialists, Belgorod State Technological University named after V.G. Shukhov. 2016, pp. 94-101. (In Russ.).

[12]H. Zhuravel, M. Shynkaryk, "Some aspects of improving the competitiveness of higher education" [Okremi aspekti pidvishchennya konkurentospromozhnosti sistemi vishchoï osviti], The Herald of Ternopil National Economic University, 2020, vol. 1, pp. 7-20. (In Ukr.). DOI: 10.35774/visnyk2020.01.007

[13]A. Kukh, O. Kukh, "Digital competence as a metacompetentity" [Tsifrova kompetentnist' yak metakompetentnist'], Collection of scientific papers of Kamianets-Podilskyi National Ivan Ohiienko University. Pedagogical series [Zbirnik naukovikh prats' Kam'yanets'Podil's'kogo natsional'nogo universitetu imeni Ivana Ogienka], 2019, pp. 30-33. (In Ukr.). DOI: $10.32626 / 2307-4507.2019-25.30-33$

[14] K. Aramyan, V. Krivopuskov, "Vocational education in the context of digital transformation: new challenges and unknown resources", Laplage em Revista, 2021, vol. 7(3D), pp. 521-532. DOI: $10.24115 /$ S24466220202173D1743 